\title{
DIDACTIC TRANSFORMATION FOR TECHNICAL EDUCATION AND TEACHER TRAINING
}

Jiř́ KROPA Č* Univerzita Palackého v Olomouci, Česká republika Jitka PLISCHKE, Univerzita Palackého v Olomouci, Česká republika Štefan CHUDÝ, Univerzita Palackého v Olomouci, Česká republika Jiř́ KROPÁČ , Univerzita Palackého v Olomouci, Česká republika

Přijato: 12. 1. 2017 / Akceptováno: 13. 3. 2017

Typ článku: Teoretická studie

DOI: $10.5507 /$ jtie.2017.009

Abstract: The aim of the text is to update and complete the issues of didactic transformation in education from aspects oriented on teacher training mainly focused on generally oriented technical education. The introduction is aimed on the reflection of the pedagogical theories which are applied in the technical education in primary school. One of the parts of the text presents new approaches in the didactics for technical education and terminological matters, after that the text discusses the actual incentives for the description of the content educational transformation. The text also presents the results of the research survey focused on the opinions of the students of the pedagogical field related to the conceptual approaches of the technical education applied in the educational transformation.

Keywords: Didactic transformation, technical education, curriculum, teacher training, primary school.

\section{DIDAKTICKÁ TRANSFORMACE PRO TECHNICKÉ VZDĚLÁVÁNÍ A PŘÍPRAVA UČITELŮ}

Abstrakt: Zámérem textu je aktualizace a doplnění problematiky didaktické transformace zhlediska prípravy učitelü pro všeobecně zaměřené technické vzdělávání. V úvodni části je text zaměřen na reflexi pedagogické teorie aplikované v technickém vzdělávání na základnich školách. Dále text předkládá nové prístupy vdidaktice technického vzdéláváni - terminologickou problematiku, následně text pojednává o aktuálních podnětech pro popis didaktické transformace obsahu. V textu jsou prezentovány výsledky výzkumné sondy názorů studentů pedagogických oborů souvisejícich s koncepčními prístupy k technickému vzdělávání, uplatňovaných při didaktické transformaci.

Klíčová slova: Didaktická transformace, technické vzdělávání, obsah vzdělávání, příprava učitelů, základní škola.

*Autor pro korespondenci: kropac@pdfnw.upol.cz 


\section{1 Úvod}

Podle rámcových vzdělávacích programů je ve školských soustavách konkretizována činnosti učitelů i obsah vzdělávání. Učitelé se podílejí na transformaci a koncipování struktury obsahu vzdělávání nejen na jeho mikroúrovni, ale také na makroúrovni. V př́ípadě technického vzdělávání na základních školách v ČR i v jiných státech (např. Velká Británie, Nizozemí, Slovensko aj.) je podíl učitelů na těchto činnostech rozsáhlý; vzájemná odlišnost zmíněné výuky je mezi školami značná (informatika, technika, robotika, základy elektrotechniky). Tvorba kurikula a didaktická transformace učiva technického vzdělávání se objevuje v mnohých publikacích, nap̌r. Bertrand (1998).

Záměrem našeho textu je, v návaznosti na monografii (Kropáč, Kropáčová, 2006), aktualizovat a doplnit problematiku didaktické transformace $\mathrm{z}$ hlediska prŕípravy učitelů pro všeobecně zaměřené technické vzdělávání na základních školách. Tato aktualizace je opřena nejen o teoretická východiska, ale i o dotazování se na názory studentů pedagogických oborů související s prrístupy $\mathrm{k}$ didaktické transformaci pro technické vzdělávání a o absolventské práce studentů (Kropáč, 2015).

Tento text i analýza monografie (Kropáč, Kropáčová, 2006) vycházejí z myšlenkového rámce zdůvodňujícího technické vzdělávání na všeobecně zaměřených školách, ten odráží skutečnost, že pro stále větší počet oblastí života jednotlivce i společnosti je typické rostoucí uplatnění sofistikovaných technických objektů a postupů. Vede to ale k závislosti na rozvoji techniky, který je spojen i s negativními jevy vedoucími až k ohrožení života na zemi (Kožuchová, 2006, s. 245). Do všeobecného vzdělávání je proto formou technických předmětů zařazována výuka témat významných pro budoucí setkání žáků s technikou, přitažlivých, navazujících na zkušenosti i předchozí poznání žáka a disponujících potencí rozvíjet žákovu osobnost. Má být zprostředkováno základní porozumění technice, vytvářeny vyvážené postoje k ní, rozvíjeny dovednosti, kompetence a jiné dispozice potřebné pro řešení problematických, nejednoznačných situací spojených s užitím techniky, viz rovněž (Blandow, Dyrenfurth, 1994).

\section{Použité metody}

V této části textu analyzujeme širší podněty a následně i př́stupy spojené s didaktickou transformací, zejména problémové komplexy úzce související s volbou koncepce vzdělávání. Byly použity metody pedagogického výzkumu: studium dokumentů, kauzální a obsahová analýza. $\mathrm{Na}$ základě těchto analýz byla provedena komparace a syntéza příslušných částí obsahu teorie vědeckých prací, absolventských prací a kurikulárních dokumentů. Syntetické činnosti vedly k formulovaným závěrům či návrhům obsaženým $\mathrm{v}$ textu.

Pro doplnění popisu vybrané problematiky a zpřesnění podmínek jejího uplatnění $\mathrm{v}$ přípravě učitelů bylo realizováno dotazníkové šetření. Jeho záměrem bylo zjistit preference studentů $\mathrm{v}$ přístupu k problémovým oblastem pojednávaného, proto žádná položka nebyla „nesprávná“. Dotazováni byli studenti pedagogických oborů bakalářských i magisterských stupňů studia, jejichž př́prava $\mathrm{v}$ oborových didaktikách ještě nebyla významně realizována. Dotazovaných bylo celkem 137, budoucích učitelů technických předmětů z toho bylo 28. Pedagogickou zkušenost již mělo 51 studentů; ovšem toto hledisko se neprojevilo jako významné. Výzkumné šetření tedy nesměřovalo k „obecně platným“ závěrům, ale spíš mělo význam obdobný akčnímu výzkumu (Nezvalová, 2003; Mcniff, 2013). Jeho výsledky jsou totiž ovlivněny prvotní zkušeností a způsobem 
předchozí přípravy studentů, které jsou popsatelné v prekonceptech o technickém vzdělávání, mj. v př́ípravě obecně pedagogické, psychologické a odborné. Ta je odlišná na různých pracovištích a intervenující proměnnou je i používaný jazyk. Vzhledem k tomuto faktu není výzkumné šetření prezentováno komplexně, pouze v elementárním zpracování jako podpora tvrzení, která prezentujeme jako širší podněty k dané problematice.

\section{3 Širší podněty pro problematiku didaktické transformace a názory studentů učitelství}

Rychle se vyvíjející technika a technologie, určené mj. ekonomickými zájmy široké populace, nastolují dosti často nové vzdělávací požadavky na všeobecné vzdělávání, zatímco jiná technická témata se stávají zastaralá. Namnoze je to paradoxně v důsledku zdokonalení dané techniky (technologie), jejíž užití se stalo pro uživatele v zásadě bezproblémové (automobil, přístroje na měření času aj.). Stále častěji se naopak setkáváme se vzdělávacími požadavky obsahujícími technická řešení, která mají celospolečenský dopad - zajištění energie, problematika odpadů, dopravních cest, hospodaření s vodou atp. Všeobecné technické vzdělávání tím podléhá změnám v čase, má užší tzv. „zlatý fond“ obsahu než jiné vyučovací předměty, podrobněji (Kropáč, Kropáčová, 2006, s. 7).

Na všechny tyto jen naznačené okolnosti je třeba adekvátně připravovat žáky a pro ně učitele. Vedou k již zmíněné heterogennosti tohoto vzdělávání na jednotlivých školách i v různých vzdělávacích soustavách, viz mj. (Serafín aj., 2016). V krajních př́ípadech se v ČR setkáme jak se základními školami, kde výuka je prioritně zacílena na zhotovení výrobku, bez snahy o rozsáhlejší technické myšlení žáka, tak se školami, kde výuka „o technice“ probíhá převážně s využitím prostředků ICT.

Podněty širší pedagogické teorie směrem ke vzdělávací praxi jsou zde tedy potřebné. V oborové didaktice technicky zaměřených předmětů v německy mluvících zemích jsme se setkali s popisem postupu didaktické transformace, který kladl na počátek této činnosti „odstup od obsahu“, zahrnující také zaujetí „společenského pohledu“ (Sesing, 2007). Jde o uvolnění se „od věci“ a s ní spojených omezujících, konkrétních podmínek. Bez toho není možný vývoj věci. Zde jde o zvážení vzdělávacích možností obsahu pro žáka i z hlediska požadavků společnosti, podrobněji také v (Kropáč, Kropáčová, 2006, s. 61).

Pro takové úvahy přináší naše pedagogická teorie významné podněty, platí nejen obecně, podle nás jsou podnětné právě pro technické vzdělávání. Hejný a Kuřina (2000, s. 38-50) poukázali v aplikaci Popperovy koncepce tří světů při vzdělávání v matematice na konstruktivistický př́stup a využití technického vzdělávání v praxi (svět 1 je svět existujících fyzických objekti̊, těles a jejich vztahů, stavů, fyzického prostředí, přírody, techniky; svět 2 je svět individuálního vědomí, myšlenkových stavů, duševních obsahů; svět 3 je svět obsahu společného myšlení lidí, zaznamenaných vědeckých a uměleckých idejí, děl, výtvorů lidského ducha).

Didaktická transformace pro technické vzdělávání s konstruktivistickým podtextem může využít jisté ,analogie“: v učivu je podle zacílení vzdělávání odrážen více či méně svět 1 a svět 3, žákovo osvojování učiva vede k proměnám žákova vědomí či myšlení (svět 2). Následovat může otázka, odkud je především sycen obsah tohoto vzdělávání a jaký má tedy charakter - na poznání čeho je vzdělávání prioritně zacíleno, zda na ,vědy o technice (svět 3) či na technickou realitu (svět 1)“. Poznamenejme - ve všeobecném technickém vzdělávání nemůže jít o poznávání jen světa 1 nebo světa 3 , jsou poznávány v sepětí. Může 
existovat názor, že prioritní je svět 1 , jenž je poznáván pomocí „prostředků či nástrojü“ ze světa 3 (pojmy, teorie, systém, metody). To předurčuje nejen uspořádání obsahu učiva, ale také procesní stránku vzdělávání.

V souvislosti se zaměřením obsahu vzdělávání prioritně na svět 1 nebo na svět 3 je důležitá odpověd' na otázku ,jaké mohou být potom před žáky kladeny problémy či v jaké logice mohou být žákovi předkládány poznatky k osvojení“. Nejprve všeobecně - při myšlení lze rozlišovat jednak poznávání „věci“ jakoby bez existence potřeb člověka; významná je zde kauzalita - vztah mezi příčinou a následkem. Další (fylogeneticky starší) je poznávání způsobu užití věci pro život, jak může ,věc“ člověku prospívat; významná je zde finalita - určenost cílem. Oba tyto systémy poznávání i poznání nelze v technickém světě oddělit. Jsme-li ale zacíleni zejména na poznávání světa 1 , potom jde především o uplatnění finality (účel - prostředek), podložené vybranými poznatky světa 3 , získanými i v jiné výuce (o technice i v netechnických předmětech) spíš postupy respektujícími kauzalitu.

Návazně má také myšlení o technice a technologiích dle Franuse (2003) dvě související stránky. Jsou to jednak procesy poznávání samotných věcí (technických zákonitostí atp.), mají charakter převážně analytický, zaměřený na vztah mezi př́íčinami a následky (kauzalita). Dále jde o procesy kreativního charakteru, např. konstruování, vytváření, zde převažuje syntéza poznaného - směřování k cíli či splnění účelu (finalita). Analýza je v technických oborech ,prríprava“ na syntetickou, účelovou činnost; na vysoký význam finality v technických oborech poukázal mj. Wolffgramm (1994) a Pexidr, Demjančuk (2009).

Studentům, viz část 2 Použité metody, počet 137, jsme předložili dvě formulace vystihující prioritní zaměření výuky, viz tab. č. 1. Měli zvolit jednu formulaci. Evidentní je preference položky 1 . U studentů učitelství technických předmětů byla tato volba ještě vyšší (průměr 1,1428 k 1,1834), z toho vyplývá, že zacílení výuky na „realitu“ je převažující. Z výsledků dotazníkového šetření lze konstatovat, že výuka „kopíruje realitu“ a nelze předpokládat zvýšení preferencí polytechnického intelektualismu, srovnej (Dostál, Prachagool, 2016, s. 10).

\begin{tabular}{|l|c|}
\hline $\begin{array}{l}1-\text { Technické předměty na ZŠ mají být zaměřeny na reálný svět techniky, } \\
\text { především na řešení situací spojených s užitím techniky. }\end{array}$ & 113 \\
\hline $\begin{array}{l}2-\text { Technické předměty na ZŠ mají být zaměřeny pokud možno } \\
\text { na systematické poznání techniky a technologií. }\end{array}$ & 24 \\
\hline
\end{tabular}

\section{Tab. č. 1: Preference zaměrení výuky}

V souladu s přístupem Štecha (2009) a s akcentováním „koncepce tří světů“ je možné koncipovat způsob prezentace učiva teorií dvou „kódů“. Pro technické vzdělávání je významným kódem integrování a charakterizace učiva, v němž „spíše než o pojmech a jejich sitich se hovoři o tématech překračujicich hranice jednotlivých předmétů ..." (Štech, 2009, s. 110). Poznatky v těchto tématech nejsou uspořádány hierarchicky, ale jsou spojeny s konkrétním tématem, situací, kontextem. Za tato témata považujeme pro vzdělávání vybrané oblasti techniky, viz výše. Zřejmá je u tohoto kódu převažující finalita $\mathrm{v}$ tomto poznávání techniky, směřování $\mathrm{k}$ aplikacím $\mathrm{v}$ technické realitě, ve světě 1 . 
Poznatky jsou do učiva začleněny podle vazby k tématu a takto jsou osvojovány v konkrétních situacích; nebyly-li osvojeny (osvojovány) v jiné výuce, př́náležející popř. kódu seriálnímu.

Kód seriální je podle nás bližší světu 3 - učivo je odvíjeno od poznání teoretického, vedoucího k obecnosti a systematičnosti (jde o základy technické a další potřebné teorie). Probíhá „... rozlišování a tř́děni kategorii jako jednotek majících vztahy kjiným jednotkám." (Štech, 2009, s. 109), jsou vyjadřovány vztahy mezi abstraktními významy (poznatky oddělené od konkrétních kontextů a situací). Zřejmý je tedy význam kauzality, je zacíleno především na analytické procesy poznávání, vymezování a potvrzování prríčinných vztahů. $\mathrm{V}$ technickém vzdělávání lze toto spatřovat, je-li založeno na některé z technických věd (např. technická mechanika, nauka o materiálech atp.). Průřrezové obsahy těchto "obecných disciplín“ mají ve vzdělávání o technice významný integrační význam (Štech, 2009, s. 110).

Při pohledu na učivo pro všeobecné technické vzdělávání na makroúrovni (Dvořák, 2009) tedy převážně nacházíme uspořádání v kódu integrovaném. Řada obsahových celků či poznatků je však v rámci některých témat průřezového charakteru (postavených na teorii, viz výše) prezentována v kódu seriálním. V tématech př́slušných kódu integrovanému jsou dále využívána a rozvíjena, podrobněji (Plischke, Kropáč, 2012), (Kropáč, 2004). Tím lze vytvářet i tzv. generalizace ve vztahu k technice (Bruner generalizace, pojmy, fakta), pro technické předměty (Kropáč, Kropáč, Plischke, 2009).

Zde se nabízí otázka, zda všeobecné technické vzdělávání má splňovat pouze záměry vyplývající z ,jejich potřebnosti“, nebo zda a do jaké míry jejich přínos má směřovat i k rozvíjení žákova „vnitřního“ světa. Obdobnou tezi vyslovil mj. Blížkovský ve svém systémovém př́istupu k vědám o výchově (1996, s. 25), cit. rovněž v (Částková, Kropáč, Plischke, 2016). Poukázal na rozvíjení či kultivaci žákova vnitřního světa, jeho vědomí, prožívání, bytí, což preferuje např. teorie pedagogického subjektivismu; dále specifikoval nutnost připravenosti na zvládání vnějšího světa a „makrosvěta“, vč. technického, což preferují teorie pedagogického objektivismu. Za nezbytné považuje propojovat obě hlediska (důrazy), ne jejich kladení ,proti sobě“.

Obdobné diskuse o optimalizaci a preferencích jednotlivých pedagogických teorií jsou hlavním tématem diskusí na fakultách připravujících budoucí učitele v EU, viz mj. (Wiesmüller, 2014). Pro všeobecné technické vzdělávání je prioritním cílem zvládání situací spojených s užitím techniky, ale i zde je významným záměrem i kritériem na obsah rozvoj žákova „vnitřního“ světa, tedy adekvátní myšlenková aktivita žáků a začlenění výchovy na základě širších souvislostí techniky (Kropáč, Chráska, 2004).

Studentům jsme předložili tři formulace odrážející jednotlivá vymezení Blížkovského a jejich propojení, viz tab. č. 2. Měli je oznámkovat jako ve škole, tedy 1 až 3 . Nejvýše byly hodnoceny formulace 1 a 3 , mezi nimi nebyl statisticky významný rozdíl. Významně níže byla hodnocena formulace 2. Je tedy nesporné, že spojení užitečnosti technických předmětů s možnostmi jejich obsahu rozvíjet myšlení a hodnotový systém není studenty všeobecně přijímáno. 


\begin{tabular}{l}
\hline Výuku v technických předmětech na ZŠ bych plánoval z tohoto pohledu: \\
\hline \hline 1 - výuka technických předmětů má být především užitečná pro budoucí život žáka. \\
\hline $\begin{array}{l}\text { - výuka technických předmětů má rozvíjet myšlení žáků a kultivovat jejich } \\
\text { hodnotový systém. }\end{array}$ \\
$\begin{array}{l}3 \text { - výuka technických předmětů má být užitečná pro žákův život a kultivovat žákův } \\
\text { duševní svět. }\end{array}$ \\
\hline
\end{tabular}

\section{Tab. č. 2: Preference př́nosu výuky}

Výsledky šetření utvrzují autory ve formulaci teze, že daná problematika není uchopena jasným stanoviskem decizních orgánů a je nutno provést v dané oblasti další výzkumná šetření longitudinálního charakteru. Za této situace ve školách je otázkou, zdali je koncipování výuky technických předmětů v souladu tři základních fenoménů, tj. obsahu, rozsahu a kultivování duševního světa žáka z pohledu jeho hodnotové orientace.

V monografii Kropáče a Kropáčové (2006, s. 49-50) byly jako základní a zajímavé z hlediska všeobecného technického vzdělávání uvedeny tyto př́stupy k vymezení obsahu - encyklopedismus, didakticky formalismus a exemplarismus. Později autoři uvedené monografie svůj pohled dále rozšírili na základě studie Macha (2011, s. 14), který uvádí př́stupy k vymezení obsahu: d. encyklopedismus, d. formalismus, d. exemplarismus, d. pragmatismus, systémový způsob - např. modulární uspořádání.

Následně byla teorie doplněna o př́istup Škody a Doulíka (2011, s. 157-161), kteří popsali následující přístupy k obsahu vzdělávání, popř. koncepce obsahu vzdělávání: d. encyklopedismus, d. formalismus, pragmatická koncepce, d. exemplarismus, funkcionální materialismus (polytechnicismus), scientismus, alternativní koncepce.

V návaznosti na tyto teoretické př́stupy je nutno specifikovat, jakou koncepci obsahu vzdělávání preferují studenti učitelství, zda spíš zaměřenou k praxi či k teorii, k materiálnímu či formálnímu. V reflexi inovované teorie, kterou považujeme za komplexní, jsme upravili pro dotazníkové šetření následující přehled koncepcí, viz tab. č. 3, ačkoli je obtížné ve stručném výroku jednotlivé koncepce charakterizovat (názvy koncepcí obsahu jsme studentům nepředložili, jsou označeny kurzívou).

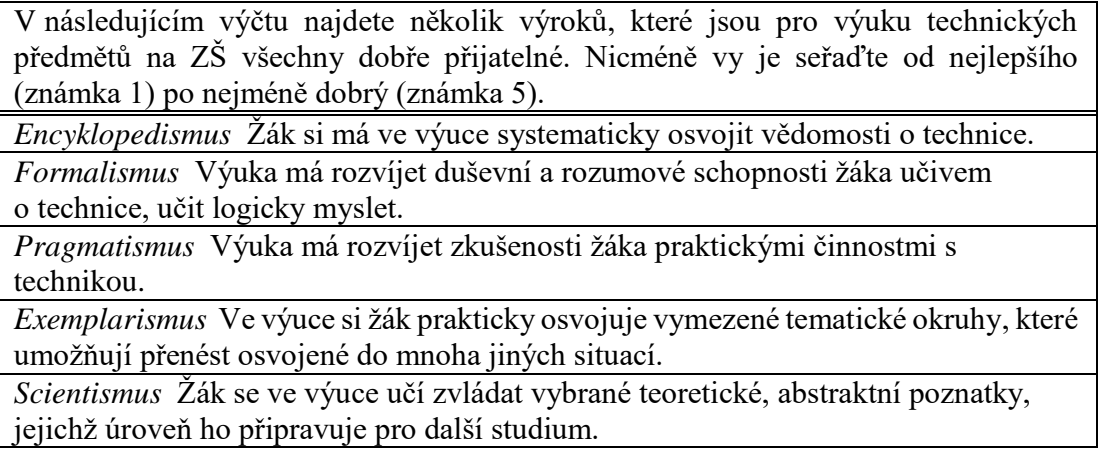

Tab. č. 3: Preference při výběru učiva či koncepce obsahu vzděláváni 
Vyjádřeno názvy koncepcí, které respondenti ale neměli k dispozici, je „celkové pořadí“ (v̌̌ech respondentů) - pragmatismus, formalismus, exemplarismus, encyklopedismus, scientismus. U studentů jiných oborů než technického zaměření byly v tomto pořadí mezi prvními čtyřmi relativně malé rozdíly, jen scientismus „byl s odstupem“. U studentů technicky zaměřených studijních oborů bylo pořadí mírně odlišné - pragmatismus, formalismus, encyklopedismus, exemplarismus, scientismus - rozdíly byly ale dosti značné. Zde je opět zřetelný „důraz na praxi“, ale překvapivé je, že exemplarizmus, jenž je ve výuce o technice vzhledem k rozsáhlosti techniky obecně nezbytný, právě technici kladli až za encyklopedismus, který ve výuce o technice v podmínkách ZŠ nelze uplatňovat. Je evidentní, že poslání, možnostem a koncepci výuky

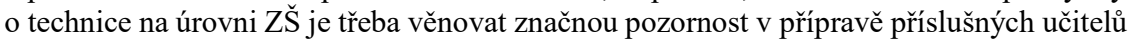
(nejen aprobovaných).

\section{Podněty všeobecného charakteru $k$ teorii didaktické transformace}

Otázkami didaktického zprostředkování vzdělávacích obsahů se podnětným způsobem zabýval Knecht (2007). Vyzdvihl koncepci didaktické rekonstrukce, tu lze podle něj „nazvat plnohodnotným modelem didaktického zprostředkováni vzdělávacích obsahů, který do procesu jejich výběru zapojuje nejen možnosti a potřeby žaků, ale také požadavky definované $v$ kurikulárnich dokumentech i ostatni aktéry a činitele ovlivňujici proces vzděláváni" (Knecht, 2007, s. 77). Ve své stati analyzoval starší i novější teorie didaktické transformace, konkrétně uvedl, že také teorie popisující didaktickou transformaci se předchozímu konstatování ve smyslu respektování možností a potřeb žáků $\mathrm{v}$ průběhu času přinejmenším přibližovaly a aspekt žáka zdůrazňovaly (Knecht, 2007, s. 78). Například tam mj. uvedený Möhlenbrock považuje didaktickou transformaci především za přetvoření vybraných vědeckých obsahů (transformandum) na zjednodušený, pro žáky srozumitelný obsah učení (transformat), přičemž jsou brány na zřetel momenty vnímání a poznávání žáků a s obsahem spjaté cíle výuky (Möhlenbrock, 1982, s. 78). Knecht ale shledal, že príistupu Möhlenbrocka chybí aspekt - „Didaktická inovace vzdělávacích obsahů: hlavní důraz je kladen na inovaci vzdělávacích obsahů s prihlédnutím ke zkušenostem $z$ každodenni výuky a praktickým potřebám žákư“ (popř. v tabulce zpětná inovace, Knecht, 2007, s. 78).

Uvedené je podnět k terminologii související s didaktickou transformací. Především za výstižný považujeme obsahově široký termín „didaktické zprostředkování vzdělávacích obsahư“, použitý v citované stati Knechta. Dále - termín didaktická transformace podle nás dobře označuje učitelovu ,činnost s obsahem“, než ten je ve vhodné formě předložen žákovi (preinteraktivní fáze), má však označovat také další „změny obsahu“ v průběhu žákova učení (interaktivní, postinteraktivní fáze); takto je ovšem v literatuře užíván méně. Je ale zřejmé, že pojem didaktická transformace úzce souvisí s obsahem vzdělávání a jeho proměnami. V tomto smyslu podle nás píší i autoři stati Slavík aj. (2014, s. 723), když mají na mysli "zvláštní zretel oborových didaktik na 'obsah vzděláváni" a jeho 'didaktickou transformaci' ve výuce s cílem obohacovat a rozvíjet žákovské dispozice, znalosti či kompetence“. Termín didaktická rekonstrukce lze podle nás dobře vztáhnout především k poznání žáka (svět 2) a jeho změnám při učení, vztahován je pochopitelně i k analýze a výkladu obsahu oboru, viz (Slavík aj., 2014, s. 732). Konstruktivistickému pojetí vzdělávání zdůrazňujícímu aspekt žáka je tato koncepce adekvátní. Neuvažujeme ale o didaktické rekonstrukci jako překonávající „dř́ivějšši“ didaktickou transformaci, významy 
obou pojmů považujeme za potřebné při oborově didaktickém myšlení ve vztahu k výuce o technice. Podle nás je nedořešená otázka, zda, kdy a do jaké míry lze dobře hovořit o rekonstruované (byt' didakticky) obsahové struktuře technického tématu, jak píší Škoda a Doulík (2011, s. 167), ovšem ne v zaměření na technickou oblast.

Pojem didaktická transformace je tedy více zaměřen na „nástroj učitele“ při vzdělávání, tedy vzdělávací obsah, popř. učivo, jež je v preinteraktivní a částečně i v interaktivní fázi ještě jen zdánlivě ,mimo žáka“, ale pro něj určeno, uzpůsobeno se snahou o maximální vzdělávací efekty. To pojem didaktická rekonstrukce je podle nás více zacílen na žákovo poznání a myšlení, na změny jeho „vnitřního světa“ v důsledku učení.

Uvedené odpovídá i dvojímu přístupu k poznávání voborových didaktikách, podrobněji mj. (Slavík aj., 2014, s. 724, 725). Jde jednak o přístup ontodidaktický, v němž jde o adekvátní způsoby konstrukce poznávání v rámci oborové didaktiky a z hlediska oboru (především sem podle nás ,zapadá“ pojem didaktická transformace). Další přístup psychodidaktický -preferuje zohlednění žáka, jeho dispozic, zkušenosti a průběhu jeho učení (za blízký problematice zde považujeme pojem didaktická rekonstrukce).

Autoři již zmíněné stati ještě uvádějí: „Kvalita propojováni ontodidaktické a psychodidaktické perspektivy ve výuce je ústredním problémem oborových didaktik stejně jako učitelù ve vzdělávaci praxi“ (Slavík aj., 2014, s. 725). Tyto myšlenky považujeme za plně oprávněné. $V$ časopisech i dalších publikacích zaměřených na didaktiku i realizační praxi technických předmětů spatřujeme statě, které již podle názvu inklinují k př́stupu ontodidaktickému (Binder, 2014), nebo psychodidaktickému (Mammes, 2014), (Schlagenhauf, 2013), nebo asi nejčastěji oba př́ístupy slučující (Schlagenhauf, 2009), (Röben, 2013); úmyslně zde uvádíme jen statě z téhož časopisu.

Položili jsme si otázku, zda při této prezentaci zmíněných pojmů didaktická transformace a didaktická rekonstrukce nebudeme narážet na odlišné subjektivní koncepce studentů pedagogických oborů. Požádali jsme je tedy, aby napsali svůj výklad významu těchto pojmů. Zde jsme se však setkali spíš s rozpaky (studenti ještě neabsolvovali didaktiku), napsali, že o pojmech neslyšeli, neznají je, nechtěli si vymýšlet, nebo si naopak evidentně vymýšleli nám pro radost. Toto zjišsění je „,pro nás“ pozitivní, studenti nemají $\mathrm{k}$ oběma porovnávaným pojmům vytvořeny natolik silné subjektivní koncepce, aby ve výuce oborové didaktiky vznikaly potíže s jejich změnou.

Nyní se blíže zaměřme na podněty ke způsobu provádění didaktické transformace. Pro zkoumání konané v rámci oborových didaktik vypracovali autoři stati (Slavík aj., 2014, s. 737-740) tzv. model hloubkové struktury výuky. Zde si povšimneme pouze tří základních vrstev modelu, jež představují, „viceméně ustálený stav obsahu ve výuce anebo stav žákových dispozic, které se k obsahu vztahuji“‘. Jsou to:

- Konceptová vrstva - představuje ,strukturu konceptů př́slušného vzdělávacího oboru, včetně specifických činností, které se k nim vztahuji“" (Slavík aj., 2014, s. 738); jde o „oborové jádro“ obsahu, je východiskem procesů výuky, jejího řízení.

- Tematická vrstva - je vztažena k žákovi, v ní se obsah žákovy dosavadní zkušenosti prolíná s obsahem oborů. Zde se uplatňuje didaktická znalost obsahu učitele, tj. schopnost ,zohledňovat učivo a možnosti a předpoklady žákü“ (Slavík aj., 2014, s. 739), př́stup z pozic žáka.

- Kompetenční vrstva - zahrnuje ,cíle výuky s ohledem na transfer nad rámec oborü“, tedy cíle „s různou mírou generalizace, v posledku až v neobecnějši rovině žákovské metakognice anebo tzv. myšleni vyššiho řádu, tj. uvažování o vlastním myšlení nebo 
jednáni a o lidském pojetí světa." Dále autoři modelu (Slavík aj., 2014, s. 739) předpokládají, „že žákova činnost $s$ určitým obsahem ve výuce vede $k$ dekontextualizaci, $k$ transferu a rozvoji obecných lidských dispozic $k$ učeni, komunikaci, ř ̌̌seni problémů apod.“"

Věnujeme této dobře dostupné stati pozornost, nebot' model hloubkové struktury výuky (dále model) lze z hlediska našich záměrů chápat jako originální teoretický popis „prostoru“ didaktické transformace. Dosud v teorii didaktické transformace převažuje popis sekvenčně uspořádané následnosti charakteristických stavů obsahů a/nebo činností, popř. doprovázený popisem činností zpětnovazebních, podrobněji (Kropáč, Kropáčová, 2006, s. 53-63). Oceňujeme tedy, že model rozlišuje (ale neodděluje) vrstvu tematickou, podle nás tvořenou didakticky transformovaným obsahem zpracovaným s požadavkem na osvojení, a vrstvu kompetenční, zohledňující vytváření kompetencí v procesu učení žáka. Tyto dvě neoddělitelné stránky výuky nebyly $\mathrm{v}$ modelech didaktické transformace dostatečně rozlišovány (např. byly zahrnuty do fází tvorby jako didaktický systém, učivo atp.). Právě pro technické předměty je model cenný tím, že umožňuje uvažovat o návaznosti pojmů, vztahů, témat, tedy jakoby o obsahu "statickém“ a o způsobu vytváření kompetencí na základě osvojeného a osvojovaného obsahu vhodně připraveným, řízeným a zajištěným procesem vzdělávání, aktivní činností žáků.

Navržené vrstvy modelu mohou být pro didaktickou transformaci pro technické vzdělávání výhodně chápány třeba jako prostory uspořádané do písmene $\mathrm{V}$, jehož základna je představována konceptovou vrstvou, ta je i podle zobrazení modelu ve stati (Slavík aj., 2014, s. 738, obr. 2) rozvíjena „operačními přechody“ k vrstvě tematické a vrstvě kompetenční. U nás by se tyto vrstvy nacházely vedle sebe, nad konceptovou vrstvou, z níž vyrůstají „, ohledem na žáka“, viz obr. č. 1. Nebudeme se pokoušet měnit označení vrstva, toto schéma ostatně považujeme za nedopracovaný návrh.

\section{vazby převážně \\ psychodidaktické}

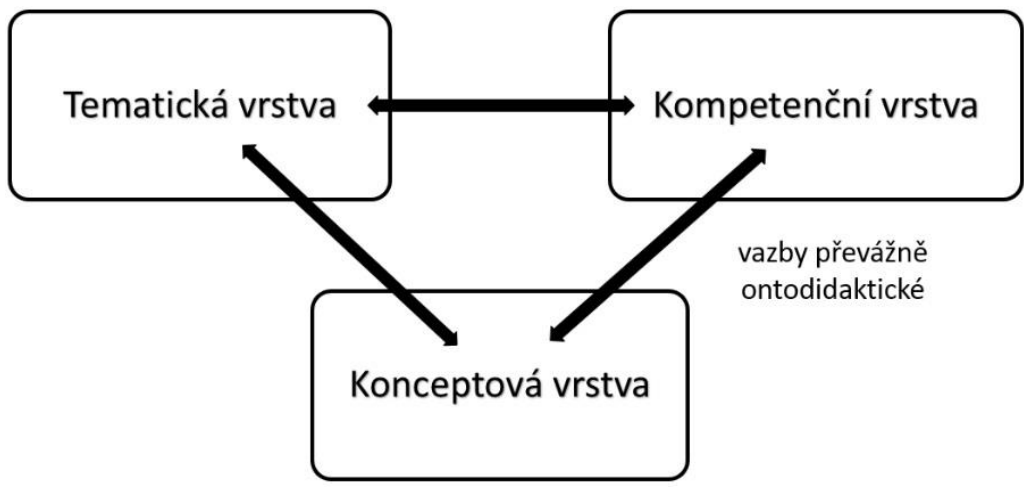

Obr. č. 1: Vrstvy didaktické transformace pro všeobecné technické vzděláváni a dominantni vztahy mezi nimi 
Předložený obr. č. 1 je vytvořen i s ohledem na přehlednost, je totiž otázka, zda by se např. prostory elips neměly částečně překrývat; např. někteří teoretikové jsou názoru, že některý odborný obsah přechází i do vzdělávání všeobecného v podstatě netransformován (uvádí se třeba měření posuvným měřítkem). Nehodláme klást tematickou vrstvu nad vrstvu kompetenční nebo naopak, tak případně vyjádřit jakousi prioritu některé z nich, i zde by bylo třeba nejprve lépe zvážit jejich „návaznost““.

Nyní z hlediska didaktické transformace pro všeobecné technické vzdělávání pojednáme obsah těchto vrstev a vztahy mezi nimi.

Vrstva nazvaná konceptová je základní, pro technické vzdělávání bude zahrnovat nejen základní pojmy či teorie oboru, ale v souladu se Skalkovou věcné a operativní vědění, sociální aktivity, hodnotové orientace i postoje (Skalková, 1999, s. 64), jež budou vstupovat do didaktické transformace. Již zde jde o nezúžený obsah všeobecného technického vzdělávání i pro základní školy; v běžných popisech didaktické transformace byl významově blízký této vrstvě tzv. „,ědecký či odborný systém obsahu“, ten ovšem je více chápán jako systém odborný, vhodný ale pro vzdělávání (Kropáč, Kropáčová, 2006, s. 54). Podle potřeb vzdělávání je pouze s ohledem na potřeby vzdělávání zvolený obsah konceptové vrstvy zdrojem obsahu vzdělávání, proto je vobr. 1 použita „obousměrná šipka“. To platí zejména v nesmírně širokém oblasti technického vzdělávání.

Tematickou vrstvu si lze představit tvořenou z konceptové, proto je v levé horní části obr. 1, v souladu s autory stati (Slavík aj., 2014) představuje prolínání žákovy zkušenosti s obsahem oboru, jsou zohledněny možnosti žáka a pozice žáka. Ve všeobecném technickém vzdělávání je třeba zohlednit žákovy budoucí potřeby pro činnost s technikou i potřeby jeho duševního rozvoje, viz výše. Aby toto bylo možné, musí být tematická vrstva dostatečně robustní a představována dostatečně různorodým, komplexním a při tom uceleným obsahem, viz (úplnost), (ucelenost). $\mathrm{Na}$ takto koncipovanou a žákům s požadavkem na osvojení adekvátně předloženou tematickou vrstvu může potom navazovat hodnotná vrstva kompetenční.

Proto musí být tematická vrstva (žákovy znalosti) oborově dostatečná pro výkon činnosti a také různorodá. Klasifikací znalostí se zabývá řada starších i novějších publikací, jmenujme zde práci Janíka (2005, s. 21-24). Také práce zaměřené na didaktiku technického vzdělávání nabízejí různé přístupy ke klasifikaci znalostí či vědomostí - funkční (vstup výstup), strukturní, technologických zákonitostí, eko-socio- technologické, dále kondicionální, hodnotové atp., viz (Röben, Wiemer, 2015). Jde ale o to, aby tato tematická vrstva byla dostatečná z hlediska chápání techniky v situacích osobních i společenských a jde také o zmíněnou dostatečnost pro dobré a široké osvojení kompetencí.

Vidíme, že osvojování techniky žákem se dosti složitě pohybuje mezi praxí (zde ji dáváme na první místo úmyslně) a související teorií a mezi znalostmi o činnosti a osvojováním činnosti. Při nemožnosti předložit žákovi adekvátní teorii bývá řada objektů pojednána jako černá skř́ňka, v rovině vstupy - výstupy. Dále v řadě prací, mj. v (Kropáč, Chráska, 2004), (Kropáč, Kropáč, Plischke, 2009), byla zdůrazněna potřeba dosahování organicky souvisejících a tedy znalostmi podložených výchovných cílů, ty představují součást tematické vrstvy, ale při činnostech konaných „, souvislosti s vrstvou kompetenční“ působí jako regulativ žákovy činnosti. Takových souvislostí mezi v podstatě statickým obsahem (př́slušným především tematické vrstvě) a jeho uplatněním při činnostech (především kompetenční vrstva) je více. 
Kompetenční vrstva je dle autorů stati (Slavík aj., 2014) charakterizována především jako nadoborová, to právě pro tzv. technické kompetence je adekvátní, jejich dobrá realizace je závislá na dodržování řady širších, tedy netechnických souvislostí (ekonomické, ochrany prostředí, estetické aj). Kompetence jsou osvojovány v technickém vzdělávání jako jinde jen konkrétní aktivní činností spojenou s adekvátním myšlením. Nutné je tedy docenění významu myšlením podložené praktické činnosti, které k širším technickým kompetencím vedou. Není snadné vytvářet podmínky, navozovat, řídit a hodnotit tuto činnost žáků. Zatímco $\mathrm{v}$ př́rodovědném vzdělávání bývá praxe „služebníkem teorie“, figuruje při její prezentaci (odvození) či prokázání, je v technických předmětech teorie určena ke „službě praxi“ (Fies, 2016). Praxe je tedy v technice cíl spočívající v jejím vytváření a užívání, neomezuje se na „ověření pravdivosti apod.“.

Myšlenkové koncepty jsou tedy v technice konfrontovány s realitou, s praxí. $\mathrm{Na}$ realizaci takto pojatého technického vzdělávání, na realizaci praxi blízkých činností je třeba učitele připravovat, i pro úroveň základních škol. Povšimněme si ještě v obr. č. 1 převažujících vazeb mezi vrstvami, vidíme, že učitel musí být připraven jak na činnosti psychodidaktické, tak ontodidaktické.

Jestliže jsme prezentovali podněty $\mathrm{k}$ terminologii i procesu didaktické transformace, povšimněme si ještě alespoň jednoho všeobecného, podle nás hlavního trendu ve změnách pohledu na to, jaký obsah je považován za potřebný ve všeobecném technickém vzdělávání na základních školách. Jde o uživatelské pojetí tohoto vzdělávání.

Stoffa a Procházková (1997) publikovali stat', v níž se zabývali uživatelským pojetím technické výchovy v rámci systému všeobecného vzdělávání. Dosti brzy tak vystihli „,trend uživatelství“, který v té době ještě nebyl tolik zřetelný jako dnes (ICT a jiná vyspělá technika, určená každému). Zmíněný trend lze ukázat i na názvu katedry stojící za časopisem JTIE. Dle (Serafín, 2009) změny probíhaly následně (letopočet přijetí názvu): 1961 - Katedra výrobní práce, 1964 - Katedra základů průmyslové výroby (popř. s fyzikou), 1980 - Katedra základů techniky, 1990/91 - Katedra technické výchovy, 2004 - Katedra technické a informační výchovy. Odklon od výrobního či průmyslového zaměření je zřejmý, „,vlídnost“ novějších pojmenování k uživatelství také. Znamená to ale, že nejen příprava žáků, ale i učitelů prochází proměnami, v př́ípadě učitelů se zvětšuje odklon od př́ípravy porovnatelné s odbornými technickými školami.

Uvedené probíhá obdobně i v zahraničí. V rozsáhlé stati upozorňuje Meier (2000) v tomto duchu na význam uplatnění hlediska životního stylu, který lze v budoucnu oprávněně očekávat, v koncepci technického vzdělávání na úrovni ISCED1 a ISCED2. Jde o zacílení na techniku v domácnosti a silný zréetel k očekávané budoucnosti žáka. Schlagenhauf (2015) se zabýval technickým vzděláváním z hlediska „všedního dne“ (Alltagstechnik), což je nepochybně v souladu se záměry všeobecného vzdělávání. To není malý úkol, podrobněji (Č́ástková, Kropáč, Plischke, 2016). Široký a různorodý okruh této běžné techniky a technologií ztěžuje vytváření systematického, dostatečnými znalostmi pojmů a zákonitostí podloženého osvojení potřebných uživatelských znalostí (tematická vrstva) i kompetencí (kompetenční vrstva). Vertikální integrace osvojovaného obsahu (podmínka vytvoření kompetencí) je zde tedy náročná - o podstatě a vnitřní stavbě objektu uživatel často velmi málo ví, konstrukce ztěžuje jeho demontáž apod. 


\section{Závěry}

Uvedené skutečnosti nás podněcují $\mathrm{k}$ vyslovení následujících závěrů a stanovisek, rozvíjejících myšlenku, že před didaktikou technického vzdělávání a před př́pravou učitelů pro toto vzdělávání stojí trvale náročné úkoly. Jsou to:

- Výše uvedené teorie mohou učitele správně nasměrovat, ale až učitelova didaktická znalost obsahu a jí podložená učitelská praxe vzdělávání o technice může zajistit úspěšné vzdělávání, vč. stránky procesní.

- V př́pravě učitelů pro technické předměty vyučované na úrovni ISCED1 a ISCED2 je třeba věnovat značnou pozornost teoriím souvisejících s celkovou koncepcí výuky, podmiňující její zaměření, cíle, volbu obsahu a procesní stránku.

- Je evidentní dlouhodobý trend spočívající v zvýšení odlišnosti koncepce př́pravy učitelů pro technické předměty vyučované na úrovni ISCED2 i ISCED3 od př́pravy technických profesionálů.

- Bylo by vítané, pokud by byla formulována sjednocující idea pro vzdělávání $\mathrm{v}$ technických předmětech na úrovni ISCED2, např̀. obdobná myšlence trvale udržitelného rozvoje, která je zvažována v prírodních vědách (Škoda, Doulík, 2009, s. 41).

\section{Literatura}

Bertrand, Y. (1998). Soudobé teorie vzdělávání. Praha: Portál.

Binder, M. (2014). Warentest - Schüler testen Laubsäge. Technik im Unterricht, Nr. 151, S. 25.

Blandow, D. \& Dyrenfurth, M. J. (1994). Technology education in school and industry: emerging didactics for human resource development. New York: Springer-Verlag.

Bližzovský, B. (1996). Úvod do systémové metodologie. In Kapitoly z metodologie pedagogiky. Brno: TEMPUS, 1996, s. 18-25.

Č́stková, P., Kropáč, J. \& Plischke, J. (2016). Přínos informálního a neformálního vzdělávání pro technické vzdělávání žákủ základní školy. Journal of Technology and Information Education, 8, č́slo 2, s. 53 - 66.

Dostál, J. \& Prachagool, V. (2016). Technology Education at a Crossroads - History, Present and Perspectives. Journal of Technology and Information Education, 8, č. 2.

Dvořák, D. (2009). Řazení učiva v soudobých teoriích kurikula. Pedagogika, 59, č. 2, s. 136-152.

Fies, H. (2016) Über den Zusammenhang von Technik und Naturwissenschaften. Technik im Unterricht, Nr. 159, S. 23-25.

Franus, E. (2003). The Dual Nature of Technical Thinking. In Technology as a challenge for school curricula. The Stockholm Library of Curriculum Studies. Stockholm: Institut of Education Press, s. $141-144$.

Hejný, M. \& Kuřina, F. (2000). Tři světy Karla Poppera a vzdělávací proces. Pedagogika, 50 , č. 1 .

Janík, T. (2005). Znalost jako klíčová kategorie učitelského vzdělávání. Brno, Paido.

Knecht, P. (2007). Didaktická transformace aneb od „didaktického zjednodušeni“ k „didaktické rekonstrukci“. ORBIS SCHOLAE, 2, č. 1, s. 67-81.

Kožuchová, M. (2006). Vedecko-technická gramotnost' jako kurikulárny problém. In Problémy kurikula základni školy. Brno: Masarykova univerzita.

Kropáč, J. \& Chráska. M. (2004). Výchova v obecně technických předmětech. Olomouc: 
Univerzita Palackého, Pedagogická fakulta.

Kropáč, J. (2004). K problému uceleného pojetí výuky obecně technických předmětů. $e$ Pedagogium (on-line), 4, č. 1, s. 60-71.

Kropáč, J., \& Kropáčová, J. (2006). Didaktická transformace pro technické předměty. Olomouc: Univerzita Palackého.

Kropáč, J. st., Kropáč, J. ml. \& Plischke, J. (2009). Ke struktuře obsahu učiva technických předmětů v základním vzdělávání - generalizace. Journal of Technology and Information Education, 1, č. 3, s. 17 - 23.

Kropáč, J. (2016). Tablet a jeho možnosti ve vzdělávání. Diplomová práce. Olomouc: Univerzita Palackého.

Mach, P. (2011). Didaktika odborného výcviku. Plzeň: Katedra matematiky, fyziky a technické výchovy fakulty pedagogické.

Mammes, I. (2014). Zum Einfluss früher technischer Bildung auf die Identitätsentwicklung. Technik im Unterricht, Nr. 151, S. 5-11.

Meier, B. (2000). Lebensstile und Alltagstechnik: Methodenkonzepte zur Zukunftsgestaltung. Unterricht-Arbeit+Technik, 2, Heft 7, s. 58-63.

Möhlenbrock, R. (1982). Modellbildung und didaktische Transformation. Bad Salzdetfurth: Verlag Barbara Franzbecker.

Mcniff, J. (2013). Action research: Principles and practice. Routledge.

Nezvalová, D. (2003). Akční výzkum ve škole. Pedagogika. 53, 2003, č. 3.

Pexidr, K. \& Demjančuk, N. (2009). Kauzalita. Plzeň: Aleš Čeněk.

Plischke, J. \& Kropáč J. (2012). Competence as an object cathegory and achieving education results komplexity. Journal of Technology and Information Education. 4, č. 1, s. 6 - 9 .

Röben, P. (2013). Technische Kompetenz und technische Bildung. Technik im Unterricht, Nr. 149, S. 5-11.

Röben, P. \& Wiemer, T. (2015). Technisches Wissen - Definition und ihre Grenzen. Technik im Unterricht, Nr. 157, S. 5-11.

Serafĩn, Č. (2009). Padesáté výročí vzniku Katedry technické a informační výchovy. In Trendy ve vzděláváni 2009. Olomouc: Univerzita Palackého, s. 3-9.

Serafin, Č. aj. (2016). Proména kurikula technické výchovy v České a Slovenské republice po roce 1989. Olomouc: Univerzita Palackého, Pedagogická fakulta.

Sesing, W. (2007). Informationstechnische Bildung [online] - [cit. 2016-10-20]. Dostupné na WWW:

darmstadt.de/bt/personen/werner_publikationen.de.jsp>.

Schlagenhauf, W. (2009) Inhalte technischer Bildung: Überlegungen zu unrer Herkunft, Legitimation und Systematik. Technik im Unterricht, Nr. 133, S. 5-13.

Schlagenhauf, W. (2013). Methoden des Technikunterrichts - Situationsanalyse und Entwicklungsperspektiven. Technik im Unterricht, Nr. 147, S. 9-16.

Schlagenhauf, W. (2015) Alltagstechnik als Gegenstand des Technikunterrichts. Technik im Unterricht, Nr. 158, S. 5-11.

Skalková, J. (1999). Obecná didaktika. Praha: ISV nakladatelství.

Slavík, J., Janík, T., Jarníková, J. \& Tupý, J. (2014). Zkoumání a rozvíjení kvality výuky v oborových didaktikách: metodika 3A mezi teorií a praxí. Pedagogická orientace, 24, č. 5, s. 721-752. 
Stoffa, J. \& Procházková, I. (1997). Používatel'ské pojatie technickej výchovy v rámci systému všeobecného vzdelávania. In Technické vzdelávanie ako súčast'všeobecného vzdelania. Banská Bystrica: Univerzita Mateja Bela, s. 111 - 114.

Škoda, J. \& Doulík, P. (2009). Vývoj paradigmat přírodovědného vzdělávání. Pedagogická orientace, 19, č. 3, s. 24-44.

Škoda, J. \& Doulík, P. (2011). Psychodidaktika: Metody efektivního a smysluplného učení a vyučování. Praha: Grada Publishing a.s.

Štech, S. (2009). Zřetel k učivu a problém dvou modelů kurikula. Pedagogika, 59, č. 2, s. 105-115.

Wiesmüller, CH. (2014) Technische Bildung und MINT - Chance oder Risiko? Nachlese zur 16. Jahrestagung der DGTB e. V. Technik im Unterricht, Nr. 154, S. 46.

Wolffgramm, H. (1994). Allgemeine Technologie. Hildesheim: Verlag Franzbecker. 